\title{
Drastic changes in the amphipod fauna (Crustacea) of Dutch inland waters during the last 25 years
}

\author{
Sjouk Pinkster, Maarten Scheepmaker, Dirk Platvoet \& Nico Broodbakker \\ Institute of Taxonomic Zoology (Zoölogisch Museum), University of Amsterdam, P.O. Box 4766, \\ 1009 AT Amsterdam, The Netherlands
}

Keywords: Netherlands, amphipods, changing distributions, allozyme electrophoresis, introduced species, environmental changes

\begin{abstract}
After the introduction of Gammarus tigrinus in The Netherlands some 25 years ago and of other recently invading amphipods (Crangonyx pseudogracilis and Corophium curvispinum) the native species decreased, the invaders increased. The success of these invaders and its impact on the local amphipod fauna is discussed. Electrophoretic tests give evidence that a second invasion of Gammarus tigrinus, this time from Germany, is taking place. Some predictions about future developments are made.
\end{abstract}

\section{Résumé}

Après l'introduction de Gammarus tigrinus aux Pays-Bas il y a environ 25 ans, ainsi que celle d'autres espèces d'Amphipodes ayant envahi le pays récemment (Crangonyx pseudogracilis et Corophium curvispinum) les espèces indigènes ont diminués considérablement et les espèces envahisseurs ont gagné du terrain. Le succès de ces invasions et leur conséquences pour les Amphipodes indigènes sont discutés. Des tests d'électrophorèse montrent qu'une seconde invasion de G. tigrinus, ayant son origine en Allemagne, se produit actuellement. Quelques prédictions sur les développements futurs sont faites.

\section{Introduction}

Until the mid sixties the gammarid fauna of Dutch inland waters was supposed to be rather stable. Most of the fresh waters were dominated by Gammarus p. pulex (Linnaeus, 1758), while G. fossarum Koch, 1836 occurred in some headwaters in the extreme south of the province of Limburg and in some isolated localities in the centre of the country
(Nijssen, 1963). G. roeseli Gervais, 1835 was restricted to some small brooks near the German border (collections Zoölogisch Museum Amsterdam = ZMA). Echinogammarus berilloni (Catta, 1878) was found in some rivers in the south of the province of Brabant and in the river Meuse and in some of its tributaries in the province of Limburg as far north as Neer, ca. $5 \mathrm{~km}$ south of Venlo (collections ZMA).

The more brackish waters, especially the IJsselmeer after the closing of the former Zuider Zee and the Frisian lakes, were populated by $G$. $d$. duebeni Liljeborg, 1851 (Schijfsma, 1954; De Vos, 1941, 1954), while G. zaddachi (Sexton, 1912), often accompanied by $G$. d. duebeni, was the dominant species in waters with tidal influences like river mouths and isolated water bodies not far from the sea. All these gammarid species are free living, benthic, and omnivorous.

The most common tube-dwelling amphipods in inland waters at that time were Corophium insidiosum (Crawford, 1937), C. multisetosum Stock, 1952, C. lacustre Vanhöffen, 1911, and C. volutator (Pallas, 1766). Two other species, C. acherusicum (Costa, 1851) and C. arenarium Crawford, 1937 were reported (collections ZMA) from marine habitats or sometimes from floating objects in inland mixohaline waters. All Corophium species are filter feeders and construct tubes of mud, of which two different types can be distinguished: (1) tubes burrowed in the substrate, which may vary from sand to soft mud, and (2) tubes that have been built 
upon a sessible substratum of any type. $C$. multisetosum, $C$. insidiosum, and C. acherusicum can make tubes of both types; the other species are exclusively burrowing.

The first intrusion upon this rather stable situation was noticed by Nijssen \& Stock (1966) reporting Gammarus tigrinus (Sexton, 1939) in The Netherlands and its rapid spreading over the IJsselmeer and canals in the northern part of the province of Noord-Holland. This finding was not very surprising, since this originally North American species was already known from a large area in England, Ireland (Hynes et al., 1960), and Germany (Schmitz, 1960).

From 1966 on, surveys (every two or three years) throughout The Netherlands have been carried out to determine eventual changes in the distribution of G. tigrinus and their impact on the local gammarid fauna; the last survey was carried out in 1991. More than 800 stations have been sampled.

\section{Material and methods}

All sampling was done with a standard dip-net, by turning stones, and by inspecting the vegetation. The population density was estimated by counting the number of assays necessary to collect a sample of at least 100 specimens. When population densities were very low, this number was not achieved. Animals were preserved in a $4 \%$ formalin solution and in the laboratory transferred to a $70 \%$ aethanol solution. For part of our research we used allozyme electrophoresis to establish the origin of some newly found populations. The animals used for these electrophoretic experiments have been transported live to the laboratory and directly deep frozen at minus $70^{\circ} \mathrm{C}$. For a further explanation of the procedure see under Electrophoretic experiments (Appendix).

\section{Developments since 1965}

The developments that took place are summarized in Pinkster et al. (1977) and Platvoet et al. (1989). During these surveys some other newcomers to the
Dutch amphipod fauna appeared on the scene: Crangonyx pseudogracilis Bousfield, 1958 (cf. Pinkster et al., 1980) and Corophium curvispinum Sars, 1895 (cf. Van den Brink et al., 1989). A summary of the developments and the actual situation is given below and in Maps 1 and 2 (for comparison see Fig. 1 in Platvoet et al., 1989, with maps of the situation in 1966, 1973, and 1986, and the map in Hautus \& Pinkster, 1987). It must be stressed that the whole country is carefully sampled (over 800 samples) but, for the ease of survey, the many hundreds of negative sampling stations have not been indicated in the present Maps 1 and 2.

Gammarus tigrinus. As can be seen from the maps in this and preceding papers, G. tigrinus rapidly spread over most meso- and oligohaline waters in The Netherlands, reaching a more or less stable situation at the end of 1979 (Pinkster et al., 1980). In the northeastern parts of the country it temporarily lost large to G. d. duebeni and G. zaddachi. Likewise, considerable variability in population densities could be observed.

Pinkster et al. (1977) demonstrated in laboratory experiments that the success of $G$. tigrinus was mainly due to its enormous reproductive capacity in oligohaline waters as compared to $G$. zaddachi, $\boldsymbol{G}$. d. duebeni, and G. p. pulex. Pinkster \& Platvoet (1983) mentioned the severe and prolonged winters of 1978/1979 and 1979/1980 and subsequent low water temperatures at the beginning of the breeding season as the main cause for the temporary decline of $G$. tigrinus population densities in the northeastern provinces. Because of these long lasting winters, ovigerous females die before the new generation can be released. G. tigrinus cannot reproduce in waters below $5^{\circ} \mathrm{C}$. This causes a dramatic decline in the population (see also Chambers, 1987).

This more or less stable situation drastically changed in 1984 and following years, when G. tigrinus not only appeared in the river Rhine and its affluents (Platvoet \& Pinkster, 1985), but also on the Frisian Isles of Texel, Terschelling, and Ameland (Hautus \& Pinkster, 1987).

During the 1991 survey, G. tigrinus was first recorded from the eastern part of the country (Map 


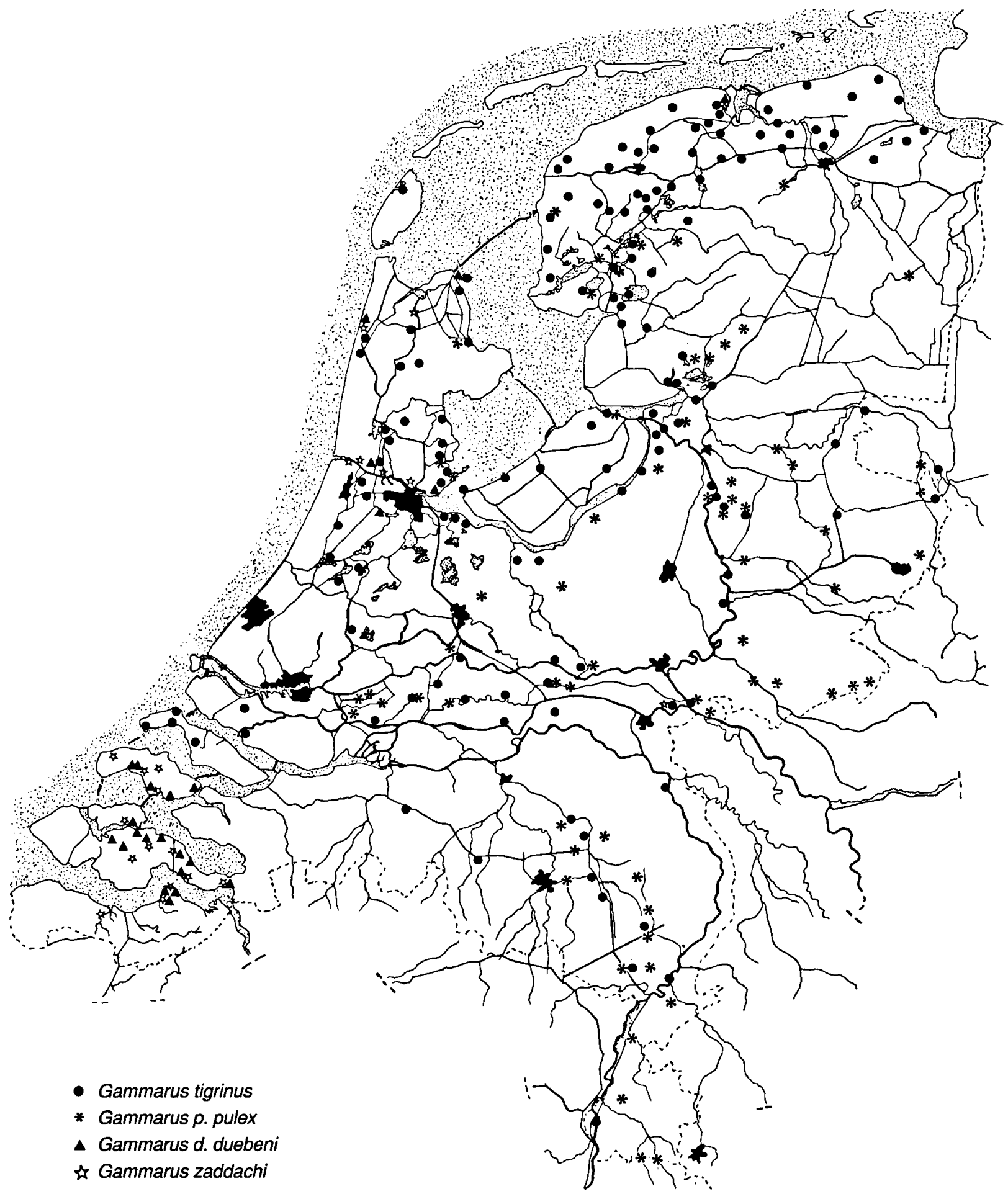

Map 1. Distribution of Gammarus tigrinus, G. zaddachi, G. d. duebeni, and G. p. pulex in The Netherlands at the end of 1991. 
1), in canals that are directly connected with the German Ems River system in which also rich $G$. tigrinus populations occur (Herhaus, 1978). Starch gel allozyme electrophoresis experiments gave evidence that these populations indeed originate from these German populations and not from the original Dutch stock. For a detailed description of these experiments we refer to the Appendix at the end of this paper.

In a few areas (e.g. in part of the Noord-Oost polder) G. tigrinus was not found again in 1991, while in other areas the population densities were very low. We assume that this is likewise caused by the severe and late winters of 1989/1990 and $1990 / 1991$. On the other hand some progress in western direction was made in the province of Noord-Brabant.

Gammarus zaddachi. As could be expected (see Pinkster et al., 1977) G. zaddachi is completely replaced by $G$. tigrinus in most of the formerly inhabited oligohaline waters in the northern provinces of Groningen and Friesland and in the Deltaic region. It is still dominant in inland waters of the Deltaic region of Rhine, Meuse, and Scheldt, in waters with chlorinities ranging from 3,000 to $10,000 \mathrm{mg}^{-1}$, and in the Noordzeekanaal that connects Amsterdam with the North Sea and in its side-canals (Van Couwelaar \& Van Dijk, 1989). It is also present in some isolated brackish water bodies behind the sea dikes. It could not take advantage of the temporary decline of G. tigrinus in the northern provinces to enlarge its range.

A new phenomenon is that $G$. zaddachi is now regularly found (although not reproducing; Van den Brink, pers. comm.) in the cooling waterintakes of the Gelderland power station in the river Waal (the main branch of the river Rhine). According to Den Hartog et al. (1989) and Van der Velde et al. (1990) this is due to the increased salinity in the last few decades.

Gammarus d. duebeni. For this species the distribution has changed even more dramatically. It disappeared from all Frisian lakes, the IJsselmeer, and canals in the provinces of Noord- and ZuidHolland. During the last few years, it was only reported from some stations in the Noordzeekanaal (Van Couwelaar \& Van Dijk, 1989), from some isolated water bodies resulting from ancient dike bursts in the province of Noord-Holland, and from the isles in the Deltaic region of Rhine, Meuse, and Scheldt.

Gammarus p. pulex. Although this species lost ground to G. tigrinus and recently also to C. pseudogracilis, it is still present throughout the country. It is the most common freshwater gammarid in natural and man-made waters, usually on sandy substrates, in the eastern and southern parts of The Netherlands. However, many of these waters are now devoid of any gammarid fauna due to severe pollution of these water systems, especially in the province of Brabant and the river Meuse between the Belgian town Liège and Venlo.

In the province of Zuid-Holland and in the areas between the large rivers Meuse, Rhine, and Waal there is a spatial separation between $G . p$. pulex and $G$. tigrinus: $G$. p. pulex inhabits the relatively unpolluted ditches, brooks, and lakes with a welldeveloped and diverse flora, while $G$. tigrinus is the dominant (often only) species in the surrounding more polluted canals and smaller rivers. This agrees completely with the observations of Van den Brink (1990). He observed a spatial segregation between G. tigrinus and G. p. pulex in the stream system of the rivers Rhine and Waal. $G$. tigrinus inhabits the major, more polluted waters, while G. p. pulex thrives best in all surrounding smaller, and less polluted waters.

In the northern provinces $G$. p. pulex can hardly maintain its position in fresh and oligohaline waters on sandy bottoms; some habitats have been lost to C. pseudogracilis or G. tigrinus, especially in the province of Groningen. It is still found in nearly all Frisian lakes, except in those in the westernmost part of the province.

Gammarus fossarum. This species is a real freshwater gammarid, inhabiting the upper reaches of relatively unpolluted streams. In the middle and lower reaches it is gradually replaced by other species (for references see Karaman \& Pinkster, 1977a: 53-54). It is very susceptible to both organic and 
inorganic pollution and higher water temperatures. This is perfectly illustrated by the gradual disappearance of the species in the province of Noord Brabant. The populations in the central part of the country, recorded by Nijssen (1963) and still present in 1970 (own observations), are now reduced to a single habitat (the Beekhuizense Beek in the national park "The Veluwezoom"). The populations in the rivers Meuse and lower Rhine, still present in 1986 (Hautus \& Pinkster, 1987), have now completely disappeared.

Gammarus roeseli. This is so far the only indigenous species that takes some advantage of the changing conditions. (According to Jażdżewski, 1980 and Karaman \& Pinkster, 1977b, this species invaded western Europe only in the last few centuries and thus also should be seen as an invader.) However, it is common in The Netherlands since the end of the last century (collections ZMA). It inhabits relatively slowly flowing rivers and can stand a high degree of organic pollution (Karaman \& Pinkster, 1977b).

Until the beginning of the ninety seventies it was only found in the extreme eastern part of the province of Gelderland, near the German border and in some waters in the province of Limburg (collections ZMA). The progressing pollution and the continuing canalization of previously natural brooks in the eastern parts of the country create an ideal environment for this species. It has now advanced in western direction into the Veluwe, a sandy and wooded area west of the river IJssel.

Echinogammarus berilloni. During our last four surveys $E$. berilloni could not be found again in the localities where it used to live in the past (collections ZMA; Moller Pillot, 1971), so we must assume that it is the only species which has completely disappeared from Dutch inland waters.

Crangonyx pseudogracilis. Like G. tigrinus this species is a newcomer to the Dutch fauna. This originally North Aiserican species was recently introduced into England and has become a common inhabitant of central and southern England and Wales since 1975. It is extending north up to York- shire, with records from some other more or less isolated populations more northward (Gledhill et al., 1976). In 1975 it was also recorded from a pond in Dublin, Ireland (Holmes, 1975). This species inhabits all kinds of habitats like rivers, canals, ponds, lakes, and reservoirs, tolerating both fresh and brackish, clean and polluted waters.

Nevertheless, its appearance in 1979 near Boerakker in the province of Groningen came more or less as a surprise. The area was well studied during many years and had rich populations of both $G . p$. pulex and $G$. tigrinus. From its first discovery, a monthly sampling programme was carried out with additional laboratory experiments in order to collect information on the biology of this so newly introduced species (Pinkster \& Platvoet, 1983). The species proved to have a high reproductive output and especially a high fecundity as compared to local species. Rapid range extension in southern and southeastern direction into the provinces of Drenthe and Friesland was to be expected. In this part of The Netherlands, stagnant or slowly flowing waters on sandy bottom prevail and G. p. pulex used to be the only gammarid species.

In the first few years after $C$. pseudogracilis was discovered however, hardly any range extension was observed. During the 1988 survey it appeared that some minor extension into southern and northern directions had taken place. In 1991 this extension continued in a more rapid way, in southern direction into the G. p. pulex area but also in northern and eastern direction into the $G$. tigrinus territory, replacing both species in many localities. Moreover, it was found far from its main distribution area, in western Friesland, in the river Eem in the province of Utrecht, and near the outlet of this river in the IJsselmeer.

Corophium species. Almost all data on the inland species of Corophium date from before the closing of the Zuider Zee and most branches of the deltaic region of the rivers Rhine, Meuse, and Scheldt (collections ZMA and reports of local and provincial water authorities). C. insidiosum, $C$. lacustre, $C$. multisetosum, and $C$. volutator used to be common in meso- and oligohaline waters in the provinces bordering the North Sea, Zuider Zee, and Wadden 
Zee. Of these four, C. lacustre and sometimes $C$. multisetosum penetrated far inland, into almost fresh waters. In our surveys before 1991 no Corophium species have been collected in the major rivers in The Netherlands, even though these rivers have been intensively sampled.

Although no specific research on Corophium has been done since the early sixties, it can be concluded from the many reports of local and provincial water authorities that all four species gradually disappeared from part of the previously inhabited areas because of the continuing decrease in salinity after the closure of the Zuider Zee and many branches in the Deltaic Region of Rhine, Meuse, and Scheldt. C. insidiosum, common in the Noordzee kanaal and connecting canals in the first half of this century (Stock, 1952) was not found again in an extensive study in 1988 (Van Couwelaar \& Van Dijk, 1989). Klink \& Moller Pillot (1982) did not find any Corophium species during an extensive study on the macro-invertebrates of the major rivers in The Netherlands.

Corophium curvispinum. After the first report of C. curvispinum Sars, 1895 in the river Rhine, close to the German border (Van den Brink et al., 1989), dramatic changes in the macrofauna of the river Rhine took place. Within a few years the small population recorded from stones of groynes grew out to dense populations with a maximum of 100,000 specimens per square metre (for comparison: the highest density ever found for $G$. tigrinus is 13,628 per square meter found in the Frisian Tjeukemeer by Chambers (1971)). This explosion first occurred in the middle Rhine in Germany and a year later in the lower Rhine over a distance of 200-500 km, indicating an enormous range extension (Van den Brink et al., 1991a). According to these authors, it now lives in all major rivers of The Netherlands, as well as in the Amsterdam-Rijn kanaal. They expected it to reach the IJsselmeer and other greater water bodies with a high silt content within short time. Indeed (although we used different gear) we found it in the IJsselmeer and some large canals in the western and eastern part of The Netherlands (see Map 2). A complete map with the present distribution of this species will be pub- lished by Van den Brink (in prep.). In the present review we only indicate not yet known localities (Map 2).

According to Van den Brink et al. (1991a) this species builds tubes on hard substrates like stones of breakwaters and river dikes. During our survey we also found $C$. curvispinum digging into the substrate, but not on hard substrates, like pebbles and dead shells, in between the groynes, in waters that are not exposed to the continuous supply of silt. More research on this topic is presently carried out at the Catholic University of Nijmegen.

\section{Conclusions}

From the data discussed in the previous sections it will be clear that enormous changes have taken place in the distribution of Amphipoda over the last 25 years, and are still continuing. Looking at the number of species one may have the impression that the amphipod fauna has become richer with the appearance of three species new to the Dutch fauna. However, a closer study reveals the contrary to be true; those species that are characteristic of certain types of habitat like G. fossarum, G. p. pulex, $G$. d. duebeni, $E$. berilloni, and to a lesser extent $G$. $z$ addachi have disappeared from a great part of the previously inhabited waters. They are now limited to more scattered areas, in which some kind of protected conditions occur (as is the case with G. fossarum in some spring regions in the south). Even more serious is the complete disappearance in a very short period (some 5 years) of amphipods from large areas (compare Maps 1 and 2 with Fig. 1 in Hautus \& Pinkster, 1987). This certainly is not due to insufficient sampling but more likely to poor environmental conditions or complete destruction of the natural habitats. This is especially true for large areas in the southern and middle part of the country, where most waters have sandy bottoms and where intensive factory farming ("bioindustry") (combined with an extreme acidification of surface and groundwaters) has led to deterioration of the water quality.

Thus, the most important factors influencing and limiting the range of the Dutch amphipod species, 


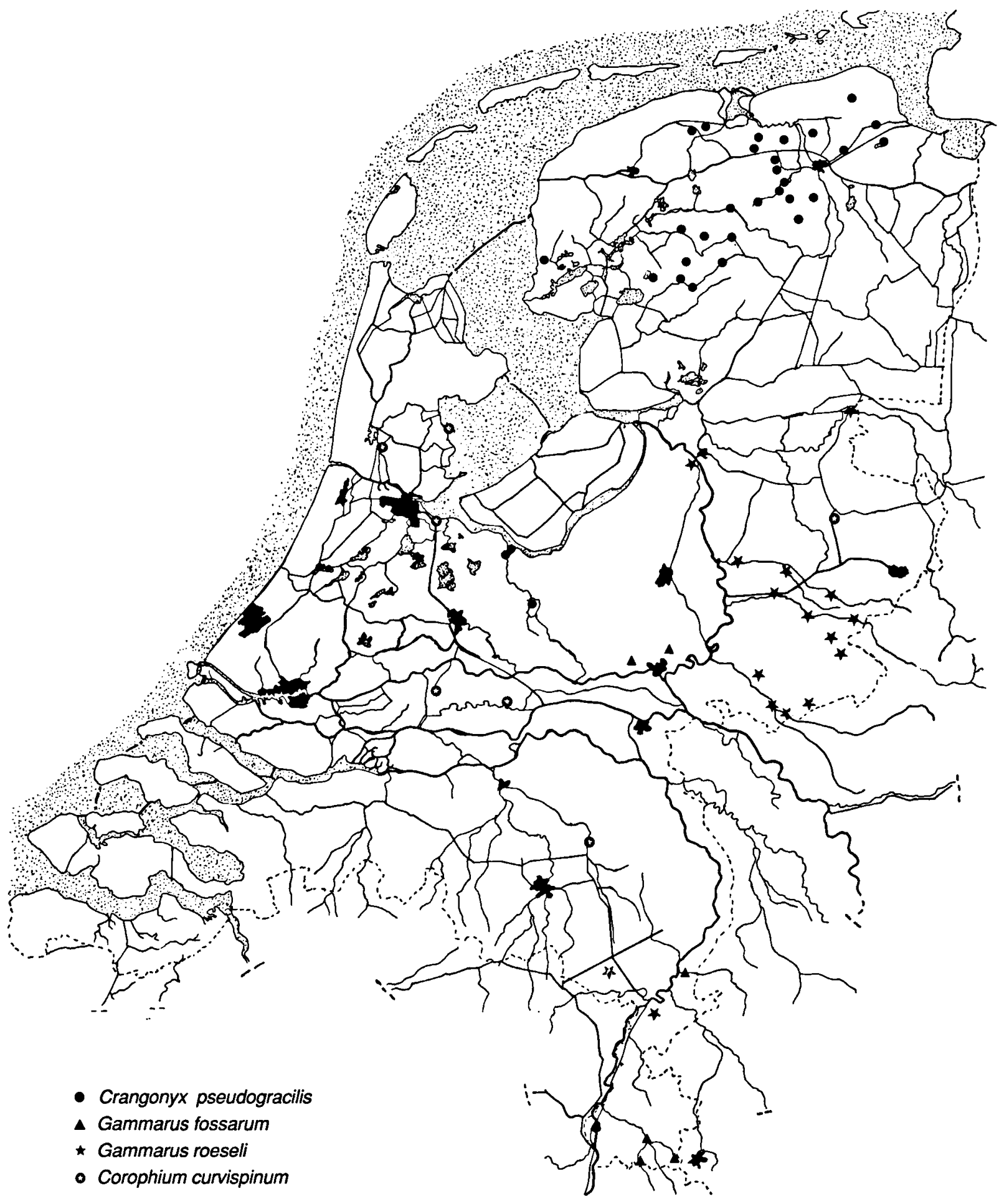

Map 2. Distribution of Crangonyx pseudogracilis, Gammarus fossarum, Gammarus roeseli, and new localities of Corophium curvispinum at the end of 1991 . 
apart from competition with local and newly introduced species, are: progressing eutrophication, increasing water temperatures, changes in salinity, acidification of both surface and groundwaters, and man-made changes in hydromorphology like canalization and construction of dams. These factors together lead to a loss in diversity and/or a complete destruction of special habitats. It is often not exactly known which is the direct cause of the disappearance of certain species, since many of the above-named factors are interacting.

In the river Meuse downstream of the highly industrialized area from Liège (Belgium) up to Venlo (Netherlands) all the factors listed above are present and a general, sharp decline of the entire macrofauna community is found. This not only causes the extinction of the formerly common $G$. fossarum and $E$. berilloni, but likewise prevents the newcomers Gammarus tigrinus and Corophium curvispinum from colonization (d'Udekem \& Stroot, 1988).

The newcomers $G$. tigrinus and $C$. pseudogracilis are both well equipped for the changing conditions in a great part of The Netherlands, viz. progressing eutrophication, increasing water temperatures, and changes in salinity and hydromorphology. They do not have high demands upon their habitat and can live in both running and stagnant waters of all sizes. They have a greater reproductive output than the indigenous Gammarus species and consequently outnumber them. Factors limiting the distribution of $G$. tigrinus are low salinities and low winter temperatures; factors limiting the distribution (chemical factors; temperature) of C. pseudogracilis are not yet fully known (for a more detailed discussion of these factors see Pinkster et al., 1977 and Pinkster \& Platvoet, 1983).

For the originally Pontocaspian species Corophium curvispinum the situation is almost ideal; it can invade a biotope in which so far no other Corophium species occurred, or from which the local Corophium species have disappeared since the damming of the Zuider Zee and most branches of the Rhine, Meuse, and Scheldt estuaries. It demands rather high water temperatures, a high ion content, and a constant supply of food and silt particles. These conditions are readily available in all major rivers and most other larger waters in The Netherlands. It can be limited by a high degree of inorganic pollution (Jażdżewski, 1980).

\section{Future developments}

It is always a hazardous venture to predict future developments but nevertheless we will try.

Gammarus tigrinus. The situation has become somewhat complicated for $G$. tigrinus with the appearance of populations originating from the German river Ems system. These German populations are descendants of an English population that has been purposely introduced into the river Werra in 1957 (Schmitz, 1960). From there it rapidly spread over most German river systems, aided by the construction of canals between the various systems, reaching the river Ems system in 1977 (Herhaus, 1978).

The Dutch $G$. tigrinus most probably originates from a population in Lough Neagh, Northern Ireland, released in the IJsselmeer on 29 July 1960. From there it rapidly spread over The Netherlands, virtually reaching the limit of its range some years ago. The German populations not only differ genetically from their Dutch congeners, as is shown in the Appendix, but they are also better adapted to life in (almost) fresh waters as can be concluded from their occurrence in fresh streams just over the German border (own observations), a habitat up to now not colonized by Dutch G. tigrinus. This opens perspectives for this population to invade uncolonized waters in the eastern provinces of Drenthe and Overijssel. It will be interesting to follow what will happen when descendants of the two stocks meet, both from the genetical and zoogeographical point of view.

In the waters up to now populated by "Dutch" $G$. tigrinus the perspective is different, since the other recent invader $C$. pseudogracilis is now entering the $G$. tigrinus territory. It has already replaced G. tigrinus in some localities in the provinces of Groningen and Friesland (1991 survey). So we must assume that in the near future $G$. tigrinus will loose some ground not just in this part of The Nether- 
lands but also in the IJsselmeer.

Gammarus zaddachi. We do not expect a change in the present situation. The waters in which it still occurs have a relatively high salinity and under these conditions its reproductive capacity is high enough to withstand the pressure of G. tigrinus. Possibly, in the long run, it will disappear again from the Rhine, when salinity drops to a considerably lower level (as will happen, according to policy makers in the countries bordering the Rhine).

Gammarus d. duebeni. This species has already been pushed back to the utmost limits of its range. Although it can thrive in waters varying from fresh to hypersaline and from unpolluted to very polluted, its reproductive capacity is too low to compete successfully with the other species now present (see Pinkster et al., 1977). It will survive only in waters with extreme conditions.

Gammarus p. pulex. Up to now, this species has withstood $G$. tigrinus in most oligohaline and fresh waters, but the introduction of $C$. pseudogracilis again has put a new pressure on its distribution. The first results can already be seen in the province of Friesland. In our opinion it will in the end be forced back into its "original" habitat, the middle reaches of fresh, running waters.

Gammarus fossarum. The situation has reached a final stage for this species. It still occurs in some upper reaches of small streams in protected areas but its disappearance from the lower reaches of these streams and the river Meuse make repopulation of other streams almost impossible, unless drastic improvement of the water quality takes place.

Gammarus roeseli shall be able to enlarge its territory, since (in spite of protests from environmentalists) canalization is still going on, creating suitable habitats for the species. There are not enough data yet to ascertain its capacity to compete with C. pseudogracilis.

Echinogammarus berilloni is already expelled from the formerly inhabited waters. Only a drastic im- provement of the water quality might possibly give it a chance to repopulate the Dutch streams in the southern part of the country from the upper regions which originate in a rather unpolluted area in Belgium.

Crangonyx pseudogracilis. After a certain period in which it has consolidated its position C. pseudogracilis has good prospects of enlarging its area since it has successfully penetrated into waters previously inhabited by G. p. pulex and G. tigrinus. It might also colonize waters so far devoid of any gammarid species. We expect to find it in due time in most canals and lakes of the provinces of Friesland, Groningen, and Drenthe, and also in the IJsselmeer, starting from its present advanced position in the mouth of the river Eem. It is hard to predict if it will be able to penetrate into the oligo- and mesohaline waters in the western part of the country, since we have no data on its reproductive capacity under these conditions.

Corophium curvispinum. As mentioned before, $C$. curvispinum entered into a habitat, which at the moment of its first appearance was not inhabited by any other tube-dwelling amphipod species. So we may expect a rapid further range expansion over a great part of The Netherlands in the years to come. This is already becoming obvious from the results of our last survey. Although no special attention was given to this species, it was found far beyond the area known at the beginning of 1991 (Van den Brink et al., 1991a; pers. comm.). During our last survey, we observed that $C$. curvispinum not only settled on the stones of groynes and dikes but was also digging into the substrate.

Although C. curvispinum is no direct competitor of the other amphipod species, its high abundance, especially on hard substrates, could have an enormous influence on the macrofauna community as a whole. It uses the same substrate and food as the mussel Dreissena polymorpha (Pallas, 1771) and Trichoptera of the genus Hydropsyche. Van den Brink et al. (1991b) already report a decline of these organisms in areas with a high density of this new invader and they predict major changes in the ecosystem as a whole. More research on this topic 
is presently done at the Laboratory of Aquatic Ecology, Catholic University Nijmegen.

Echinogammarus ischnus. A possibility that so far has not been discussed is the eventual appearance of Echinogammarus ischnus (Stebbing, 1906) in the eastern part of The Netherlands. This originally Pontocaspian species has rapidly spread over Europe in the last few decades and reached the German river Ems system in 1978 (Herhaus, 1978). In spite of our intensive sampling, we did not yet find it in The Netherlands, but it seems most likely that in due time this species will also enter the Dutch inland waters.

\section{Acknowledgements}

The authors are indebted to the Beyerinck-Popping Fonds of the Royal Dutch Academy of Sciences for their support in financing the fieldwork, to the many employees of local water authority boards for providing information, and to Drs. F.W.B. van den Brink of the Laboratory of Aquatic Ecology, Catholic University Nijmegen, for giving information and critical remarks.

\section{References}

Brewer, G.J., 1970. An introduction to enzyme technics: 1-186 (Academic Press, London).

Brink, F.W.B. van den, 1990. Classification and valuation of floodplain-waters of large rivers in The Netherlands, based on aquatic macrophytes, plankton, and macro-invertebrates, in relation with physico-chemical parameters. Publications and Reports on the Project "Ecological Rehabilitation of the River Rhine", 25: 1-158 (Vakgroep Aquatische Oecologie, Katholieke Universiteit Nijmegen).

Brink, F.W.B. van den, G. van der Velde \& A. bij de Vaate, 1989. A note on the immigration of Corophium curvispinum (Crustacea: Amphipoda) into the Netherlands via the river Rhine. Bull. zoöl. Mus. Univ. Amsterdam, 11 (26): 211-213.

Brink, F.W.B. van den, G. van der Velde \& A. bij de Vaate, 1991 a. Amphipod invasion on the Rhine. Nature, 352 (6336): 576.

Brink, F.W.B. van den, G. van der Velde \& A. bij de Vaate, 1991b. Slijkgarnaal bedreigt Rijnfauna. Bionieuws, 1 (1): 7.

Bulnheim, H.P., 1985. Genetic differentiation between natural populations of Gammarus tigrinus (Crustacea, Amphipoda) with reference to its range extension in European continental waters. Arch. Hydrobiol., 102: 273-290.

Chambers, M.R., 1971. Studies on the littoral fauna of Tjeukemeer: 1-128 (Ph. D. thesis, Univ. Liverpool).
Chambers, M.R., 1987. The status of the alien amphipod Gammarus tigrinus (Sexton, 1939) in Friesland twenty years after its introduction into the Netherlands. Bull. zoöl. Mus. Univ. Amsterdam, 11 (7): 65-67.

Couwelaar, M. van \& J. van Dijk, 1989. Onderzoek oeverfauna Noordzeekanaal, zijkanalen en havens: 1-50, I-XI (Rijks Waterstaat Noord-Holland, nota ANW 89.17).

Gledhill, T., D.W. Sutcliffe \& W.D. Williams, 1976. Key to the British freshwater Crustacea: Malacostraca., Scient. Publ. Freshwat. biol. Ass., 31: 1-72.

Hartog, C. den, F. van den Brink \& G. van der Velde, 1989. Brackish-water invaders in the river Rhine. A bioindication for increased salinity level over the years. Naturwissenschaften, 76: 80-81.

Hautus, T. \& S. Pinkster, 1987. Range extension in the period 1985-1986 of the alien amphipods, Gammarus tigrinus Sexton, 1939, and Crangonyx pseudogracilis Bousfield, 1958, in the Netherlands (Crustacea, Amphipoda). Bull. zoöl. Mus. Univ. Amsterdam, 11 (6): 57-64.

Herhaus, K.F., 1978. Die ersten Nachweisen von Gammarus tigrinus Sexton, 1939 und Chaetogammarus ischnus (Stebbing, 1906) (Crustacea, Amphipoda, Gammaridae) im Einzugsgebiet der Ems und ihre Verbreitungsgeschichtliche Einordnung. Natur und Heimat, 38 (3): 71-77.

Holmes, J.M.C., 1975. Crangonyx pseudogracilis Bousfield, a freshwater amphipod new to Ireland. Ir. Nat. J., 18: 225-226.

Hynes, H.B.N., T.T. Macan \& W.D. Williams, 1960. Key to the British species of Crustacea: Malacostraca occurring in fresh water. Scient. Publs. Freshwat. biol. Ass., 19: 1-36.

Jażdżewski, K., 1980. Range extensions of some gammaridean species in European inland waters caused by human activity. Crustaceana, Suppl. 6: 84-107.

Karaman, G. \& S. Pinkster, 1977a. Freshwater Gammarus species from Europe, North Africa and adjacent regions of Asia (Crustacea-Amphipoda). Part I. Gammarus pulex-group and related species. Bijdr. Dierk., 47 (1): 1-97.

Karaman, G. \& S. Pinkster, 1977b. Freshwater Gammarus species from Europe, North Africa and adjacent regions of Asia (Crustacea-Amphipoda). Part II. Gammarus roeseli-group and related species. Bijdr. Dierk., 47 (2): 165-196.

Klink, A.G. \& H. Moller Pillot, 1982. Onderzoek aan de makroinvertebraten in de grote Nederlandse rivieren: 1-57 (Report Hydrobiologisch Adviesburo A.G. Klink, Wageningen/Tilburg).

Menken, S.B.J., 1981. Host race and sympatric speciation in small ermine moths, Yponomeutidae. Entomologia exp. appl., 30: 280-292.

Moller Pillot, H.K.M., 1971. Faunistische beoordeling van de verontreiniging in laaglandbeken: 1-286 (Ph. D. thesis, Catholic University Nijmegen).

Nijssen, H., 1963. Some notes on the distribution and the ecology of the amphipod Gammarus fossarum Koch, 1835, in the Netherlands (Crustacea, Malacostraca). Beaufortia, 10 (116): 40-43.

Nijssen, H. \& J.H. Stock, 1966. The amphipod Gammarus tigrinus Sexton, 1939, introduced in the Netherlands (Crustacea). 
Beaufortia, 13: 97-206.

Pinkster, S., J. Dieleman \& D. Platvoet, 1980. The present position of Gammarus tigrinus Sexton, 1939, in the Netherlands, with the description of a newly discovered amphipod species, Crangonyx pseudogracilis Bousfield, 1958 (Crustacea, Amphipoda). Bull. zoöl. Mus. Univ. Amsterdam, 7 (4): 33-45.

Pinkster, S. \& D. Platvoet, 1983. Further observations on the distribution and biology of two alien amphipods, Gammarus tigrinus Sexton, 1939, and Crangonyx pseudogracilis Bousfield, 1958, in the Netherlands. Bull. zoöl. Mus. Univ. Amsterdam, 9 (17): 153-164.

Pinkster, S., H. Smit \& N. Brandse-de Jong, 1977. The introduction of the alien amphipod Gammarus tigrinus Sexton, 1939, in the Netherlands and its competition with indigenous species. Crustaceana, Suppl. 4: 91-105.

Platvoet, D. \& S. Pinkster, 1985. The present position of the alien amphipods Gammarus tigrinus and Crangonyx pseudogracilis in the Netherlands (Crustacea, Amphipoda). Bull. zoöl. Mus. Univ. Amsterdam, 10 (16): 125-128.

Platvoet, D., M. Scheepmaker \& S. Pinkster, 1989. The position of two introduced amphipod crustaceans, Gammarus tigrinus and Crangonyx pseudogracilis in the Netherlands during the period 1987-1988. Bull. zoöl. Mus. Univ. Amsterdam, 11 (24): 197-202.

Scheepmaker, M., 1990. Genetic differentiation and estimated levels of gene flow in members of the Gammarus pulex-group (Crustacea, Amphipoda) in western Europe. Bijdr. Dierk., 60 (1): 33-30.

Scheepmaker, M., F. van der Meer \& S. Pinkster, 1988. Genetic differentiation of the amphipods Gammarus ibericus Margalef, 1951 and G. gauthieri S. Karaman, 1935, with reference to some related species in France. Bijdr. Dierk., 58 (2): 205-226.

Schijfsma, K., 1954. Amphipoda. Flora Fauna Zuiderzee, 3: 195-204 (De Boer, Den Helder).

Schmitz, W., 1960. Die Einbürgerung von Gammarus tigrinus auf dem Europäischen Kontinent. Arch. Hydrobiol., 57 (1/2): 223-225.

Siegismund, H.R.V., V. Simonsen \& S. Kolding, 1985. Genetic studies of Gammarus. I. Genetic differentiation of local populations. Hereditas, 102: 1-13.

Stock, J.H., 1952. Some notes on the taxonomy, the distribution and the ecology of four species of the amphipod genus Corophium (Crustacea, Malacostraca). Beaufortia, 2 (21): $1-10$.

d'Udekem d'Acoz, C. \& P. Stroot, 1988. Note sur l'expansion de Corophium curvispinum Sars, 1895 en Meuse (Crustacea, Amphipoda: Corophiidae). Annls. Soc. r. zoöl. Belg., 118 (2): 171-175.

Velde, G. van der, F.W.B. van den Brink, R. van der Gaag \& P.J. Bergers, 1990. Changes in the numbers of mobile macroinvertebrates and fish in the river Waal in 1987, studied by sampling the cooling-water intake of a power plant: first results of a Rhine biomonitoring project. Limnologie aktuell, 1: 325-342.

Vos, A.P.C. de, 1941. Zoölogische resultaten van een tocht rond het IJsselmeer van 5-8 juli 1937. Meded. Zuiderzee-Comm. ned. dierk. Vereen., 5: 37-50.

Vos, A.P.C. de, 1954. De littorale fauna van het IJsselmeer. Flora Fauna Zuiderzee, 3: 268-276 (De Boer, Den Helder).

Weir, B.S. \& C.C. Cockerham, 1984. Estimating F-statistics for the analysis of population structure. Evolution, 38 (6): 1358-1370.

Workman, P.L. \& J.D. Niswander, 1970. Population studies on southwestern Indian tribes. II. Local genetic differentiation in the Papago. Amer. J. hum. Genet., 22: 24-49.

\section{Appendix}

\section{Electrophoretic experiments}

In order to find out whether Gammarus tigrinus reached the eastern part of The Netherlands from the original Dutch stock, or from the German stock, electrophoretic research was carried out. The genetic variation of three population samples from (1) the eastern Netherlands, (2) the Ems drainage system in Germany, and (3) from the western Netherlands was investigated at seven presumptive gene loci. These populations were sampled at the following stations:

(1) Overijsselsch Kanaal, E. of bridge in Hardenberg, prov. Overijssel, Netherlands, 12-IX-1991.

(2) Speller Aa, $1 \mathrm{~km}$ West of Spelle (N. of Rheine), NordRheinland Westfalen, Germany, 12-IX-1991.

(3) Nauernaasche Vaart, near bridge at Assendelft, prov. Noord-Holland, Netherlands, 13-IX-1991.

Electrophoresis and staining procedures generally followed Siegismund et al. (1985), Bulnheim (1985), and Scheepmaker et al. (1988). The following enzymes were assayed (E.C. numbers between parentheses): GOT = Glutamic oxaloacetic transaminase (2.6.1.1); PGI = Glucose phosphate isomerase (5.3.1.9); GPT = Glutamate pyruvate transaminase (5.4.2.2); IDH = Isocitrate dehydrogenase (1.1.1.42); MPI = Mannose phosphate isomerase (5.3.1.8); PEP = Peptidase, substrate leu-gly-gly (3.4.11/13); $\mathrm{PGM}=$ Phosphoglucomutase (5.4.2.2). Electrophoretics and staining procedures followed Brewer (1970).

The three population samples revealed to be polymorphic at the seven investigated enzyme loci. However, Gpi and Got-l exhibited a low degree of polymorphism. Electromorph frequencies and relative mobilities are listed in Table $\mathrm{I}$.

Population subdivision (Table II) was investigated by calculating the among population variance in allele frequencies data $\left(F\right.$-statistics $\left(F_{s t}\right)$, after Wright, 1931, modified by Weir \& Cockerham, 1984; for details see Scheepmaker, 1990). Among homogeneous populations, $F_{s t}$ is expected to be very close to 0 . Significance of departures from 0 were tested with a chi-square heterogeneity test (Workman \& Niswander, 1970).

Table II shows that the electromorph distribution among the 3 population samples is significantly subdivided at 4 out of 7 loci at the 0.05 level; these figures are 3 out of 7 for sample 1 vs. sample 3; 5 out of 7 for sample 2 vs. sample 3; and 1 out of 7 for 
Table I. Electromorph frequencies at 7 gene loci.

\begin{tabular}{|c|c|c|c|c|c|}
\hline station & & 1 & 2 & 3 & $P=(1-q)^{n}$ \\
\hline \multicolumn{6}{|c|}{ locus electromorph } \\
\hline & $(\mathrm{N})$ & 45 & 45 & 45 & \\
\hline & a & 0.00 & 0.00 & 0.02 & 0.135 \\
\hline & b & 0.01 & 0.01 & 0.00 & 0.369 \\
\hline & c & 0.99 & 0.98 & 0.98 & \\
\hline & d & 0.00 & 0.01 & 0.00 & \\
\hline & $h$ & 0.02 & 0.04 & 0.04 & \\
\hline \multicolumn{6}{|l|}{ Gpi } \\
\hline & $(\mathrm{N})$ & 45 & 45 & 45 & \\
\hline & $a$ & 0.02 & 0.08 & 0.00 & 0.135 \\
\hline & b & 0.00 & 0.00 & 0.03 & 0.048 \\
\hline & c & 0.04 & 0.01 & 0.00 & 0.369 \\
\hline & d & 0.90 & 0.87 & 0.96 & \\
\hline & e & 0.00 & 0.03 & 0.00 & \\
\hline & f & 0.03 & 0.01 & 0.00 & 0.369 \\
\hline & g & 0.00 & 0.00 & 0.01 & 0.369 \\
\hline & $h$ & 0.20 & 0.27 & 0.07 & \\
\hline \multicolumn{6}{|l|}{$G p t$} \\
\hline & $(\mathrm{N})$ & 45 & 45 & 45 & \\
\hline & a & 0.23 & 0.30 & 0.00 & $\ll 0.0001$ \\
\hline & b & 0.00 & 0.01 & 0.22 & \\
\hline & c & 0.77 & 0.69 & 0.98 & \\
\hline & $h$ & 0.47 & 0.51 & 0.04 & \\
\hline \multicolumn{6}{|l|}{$I d h-1$} \\
\hline & $(\mathrm{N})$ & 27 & 20 & 28 & \\
\hline & a & 0.19 & 0.30 & 0.00 & $\ll 0.0001$ \\
\hline & b & 0.82 & 0.70 & 1.00 & \\
\hline & $h$ & 0.22 & 0.50 & - & \\
\hline \multicolumn{6}{|l|}{$M p i$} \\
\hline & $(\mathrm{N})$ & 37 & $40^{*}$ & 40 & \\
\hline & $\mathbf{a}$ & 0.61 & 0.74 & 0.64 & \\
\hline & b & 0.10 & 0.03 & 0.04 & \\
\hline & c & 0.19 & 0.10 & 0.20 & \\
\hline & $\mathrm{d}$ & 0.11 & 0.14 & 0.13 & \\
\hline & $h$ & 0.35 & 0.28 & 0.40 & \\
\hline
\end{tabular}

Pep

$\begin{array}{cccc}\text { (N) } & 26 & 40 & 31 \\ \text { a } & 0.19 & 0.13 & 0.26 \\ \text { b } & 0.50 & 0.41 & 0.57 \\ \text { c } & 0.31 & 0.46 & 0.18 \\ h & 0.39 & 0.33 & 0.58\end{array}$

$P g m$

\begin{tabular}{ccccc} 
(N) & 44 & 45 & 45 & \\
a & 0.33 & 0.16 & 0.40 & \\
b & 0.53 & 0.60 & 0.60 & \\
c & 0.14 & 0.24 & 0.00 & $\ll 0.0001$ \\
$h$ & 0.59 & 0.64 & 0.40 & \\
\hline H & 0.32 & 0.37 & 0.36 & \\
\hline
\end{tabular}

$\mathbf{N}=$ sample size; $\boldsymbol{h}=$ heterozygosity per locus (direct count); $\mathrm{H}=$ mean heterozygosity over all loci; ${ }^{*}=$ significant departure from Hardy-Weinberg distribution $(P<0.05$ ); electromorph designation from fastest to slowest in alphabetical order; frequencies of "discriminative" alleles between samples $1 \& 2$ vs. 3 in bold face.
Table II. F-statistics $\left(F_{s t}\right)$ according to Weir \& Cockerham (1984) of different combinations of the population samples studied.

\begin{tabular}{lllll}
\hline stations & $1,2 \& 3$ & $1 \& 2$ & $1 \& 3$ & $2 \& 3$ \\
\hline locus & & & & \\
Got-1 & 0.00 & 0.01 & 0.00 & 0.00 \\
Gpi & 0.02 & 0.01 & $0.02^{*}$ & $0.04^{* *}$ \\
Gpt & $0.22^{* *}$ & 0.00 & $0.30^{* *}$ & $0.28^{* *}$ \\
Idh-1 & $0.15^{* *}$ & 0.01 & $0.40^{* *}$ & $0.33^{* *}$ \\
Mpi & 0.00 & 0.01 & 0.01 & 0.00 \\
Pep & $0.03^{*}$ & 0.01 & 0.00 & $0.08^{* *}$ \\
Pgm & $0.05^{* *}$ & $0.03^{*}$ & 0.01 & $0.09^{* *}$ \\
Mean & 0.08 & 0.01 & 0.08 & 0.13 \\
\hline
\end{tabular}

${ }^{*}=P<0.001 ;^{* *}=P<0.0001$.

sample 1 vs. sample 2 ; mean $F_{\text {st }}$ values are $0.08,0.01,0.08$, and 0.13 , respectively.

As samples 1 and 2 are more homogenous with regard to each other than any other combination, the populations in the eastern part of The Netherlands most probably originate from the Ems system in Germany and not from the original Dutch population in the western part of The Netherlands.

Electromorphs occurring either in sample 1 and 2, or in sample 3 are indicated in bold face in Table $I$. The probability that such an electromorph occurred in the population of sample 3 (or, vice versa in samples 1 and 2), but that it was not detected due to sampling errors is given by $(1-q)^{n}$ (Menken, 1981). In this formula $q$ is the electromorph frequency in the sample electromorph where it is present, and $n$ twice the sample size (when a subset of samples exhibiting such an electromorph is compared to one in which it was not detected, the lowest frequency was used).

Table I shows that most of such discriminative electromorphs are far from being diagnostic. However, the probability that the three electromorphs $G p t^{\alpha}, I d h-I^{\alpha}$, and $P g m^{c}$ encountered in sample 1 and sample 2 are absent in sample 3 due to a sampling error is $\ll 0.0001$. The absence of these three electromorphs in the latter population corroborates the hypothesis that the $G$. tigrinus populations found in the eastern part of The Netherlands originate from German populations and not from the original Dutch stock.

Received: 4 October 1991 